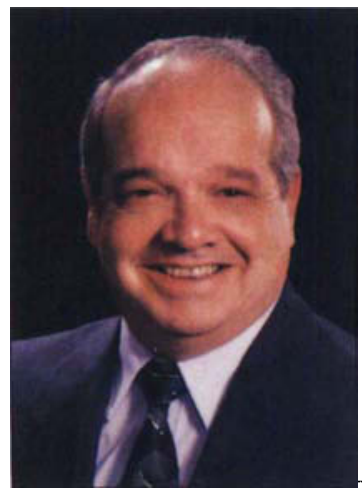

\title{
No final answers for some research enigmas
}

\section{W.R. GOMES \\ Vice President \\ Agriculture and Natural Resources}

(As California Agriculture celebrates its 50th year of publication, we revisit the topics originally raised by former UC President Robert Gordon Sproul, in a commentary published in the first issue of December, 1946. - Ed.)

"There are underway at present, or just completed, 839 research projects in the College of Agriculture. Some of these agricultural enigmas, like Pierce's disease of grapevines, and mastitis in dairy cattle, still baffle the scientists." - former UC President Robert Gordon Sproul in the first California Agriculture, 1946

Sproul's sentiment is remarkably current today. Although Division projects now number more than 1,100, scientists still struggle with the problems of Pierce's disease and mastitis.

In fact, most scientific progress is made with no dramatic victory in sight. The battle against agricultural pests is never won; there are only brief respites when science temporarily gains the advantage. New pests are introduced; existing pests develop resistance or evolve into new, more destructive forms.

One example is grape phylloxera - an insect the size of a pinhead that has recently caused a wave of destruction in Napa and Sonoma vineyards (see pages 9-23).

Phylloxera is nothing new. In 1880, it was the major impetus to form the predecessor of the California Department of Food and Agriculture. That year the Legislature appointed a seven-member State Board of Viticulture, precipitated by a need to protect grape vines from phylloxera root rot. That governmental body would eventually evolve into a single department of agriculture, created by the state in 1919.

But grape phylloxera would prove a formidable foe. From 1850 to 1910, the insect would decimate vineyards in Europe and California, destroying more than 75,000 acres of California grapes alone, the equivalent of more than 46 million grapevines. Their value in yield at today's prices would be close to $\$ 450$ million.

In the early 1900s, UC scientists began to identify practical solutions: resistant rootstocks, particularly AxR\#1, a hybrid of the European Vitis vinifera and the phylloxera-resistant American species Vitis rupestris. But this solution proved temporary; it failed first in France and South Africa at the turn of the century.

It would fail, much later, in California.

Like some other diminutive life forms, phylloxera is a versatile enemy. The tiny plant louse pierces grapevine roots, injects saliva and sucks nutrients. Scientists believe its saliva contains mimics of the plant's own hormones, and - if a root- stock becomes susceptible - it triggers abnormal growth called a gall. In roots where the gall forms, the insects thrive and the vines rapidly decline. In roots where the gall does not form, the plant is "resistant" and safe - at least temporarily.

AxR\#1 was a productive California rootstock until the 1980s. In 1983, it began to succumb to pressure from a strain of phylloxera with a slightly altered chemistry, called "biotype B." Scientists have recently determined that phylloxera is much more variable than originally thought; wherever biotype A exists, there is a potential for biotype B to emerge (see p. 9).

UC researchers have now found another practical, but temporary, solution to the biotype B problem. They have identified many resistant rootstocks which are all hybrids of three or four American species. (Since phylloxera is native to the Eastern United States, and coevolved with wild grape species there, these American species are highly resistant.)

In the planting boom from 1960 to 1980,60 to $70 \%$ of Napa and Sonoma vineyards were planted to the now susceptible AxR\#1. Virtually all must be replanted. This cost, plus production losses, represents a toll of $\$ 750$ million to $\$ 1.25$ billion.

Fortunately for wine grape growers, a number of factors have increased the price of wine grapes and eased the financial blow, including soaring consumer demand and an undersupply of wine grapes (see p. 7 ). Already, 35 to $40 \%$ of acres have been replanted.

But basic questions remain to be answered: What makes a rootstock susceptible or resistant? What does the insect obtain when it eats the plant roots and stimulates the gall formation? Does the insect cause the plant's decline or does it simply create a wound through which other devastating organisms attack?

The history of phylloxera research is exemplary of many struggles. Scientists have scored a long succession of temporary successes, but seldom vanquish a pest or disease. Phylloxera, mastitis and Pierce's disease may be with us forever. Occasionally problems are solved and gone, as long as we are vigilant. So far, such success stories are scant. Small pox vaccines have all but eliminated this disease worldwide. One disease of cattle - screwworm or miasis - has been prevented by biological control, but a continuous international effort is required to avoid reintroducing screwworm into the United States.

There is no final answer to phylloxera, or to many agricultural problems. Each answer has a life span; agricultural pests change as biology, technology, and economics change.

The questions plaguing California agriculture are as old as cultivation itself. Once again, we have found rootstocks resistant to biotype B. Once again, we have solved the problem, for now. 